\title{
STRES W ŚRODOWISKU PRACY STRAŻAKÓW
}

\section{STRESS IN THE FIREFIGHTERS' WORKING ENVIRONMENT}

\author{
Piotr Paweł Oskwarek ${ }^{1(\mathrm{~A}, \mathrm{~B}, \mathrm{C}, \mathrm{D}, \mathrm{F})}$, Małgorzata Tokarska-Rodak ${ }^{1(\mathrm{D}, \mathrm{E}, \mathrm{F})}$
}

${ }^{1}$ Państwowa Szkoła Wyższa im. Papieża Jana Pawła II w Białej Podlaskiej,

Katedra Zdrowia, Zakład Zdrowia Publicznego

Oskwarek P.P., Tokarska-Rodak M. (2017), Stres w środowisku pracy strażaków. Rozprawy Społeczne, 11 (2), s. 57-61.

Wkład autorów:

A. Zaplanowanie badań

B. Zebranie danych

C. Dane - analiza i statystyki

D. Interpretacja danych

E. Przygotowanie artykułu

F. Wyszukiwanie i analiza

literatury

G. Zebranie funduszy
Tabele: 1

Ryciny: 1

Literatura: 18

Otrzymano: 18.11 .2016

Zaakceptowano: 31.01.2017

\begin{abstract}
Streszczenie
Wstęp. Celem pracy było określenie źródeł stresu zawodowego w opinii strażaków, analiza sposobów radzenia sobie z nim oraz analiza rodzaju deklarowanych symptomów zdrowotnych występujących w związku ze stresem zawodowym.

Materiał i metody. Grupę badaną stanowiło 110 strażaków Podziału Bojowego Komendy Miejskiej Państwowej Straży Pożarnej w Białej Podlaskiej. Badania przeprowadzono na przełomie roku 2014/2015, zastosowano metodę sondażu diagnostycznego i autorski kwestionariusz ankiety.

Wyniki. 22\% ankietowanych strażaków deklaruje, że nie odczuwa stresu podczas wykonywania czynności związanych z wykonywanym zawodem. Największym źródłem stresu dla ankietowanych była odpowiedzialność za życie osób ratowanych (38\%) i presja czasu w podejmowaniu decyzji (25\%). Deklarowano zdrowotne symptomy stresu: przyspieszony oddech, tętno, podwyższone ciśnienie $(25,5 \%)$, rozdrażnienie $(22,6 \%)$, zmęczenie $(22,6 \%) ; 18,2 \%$ ankietowanych korzystało z pomocy psychologa, z zasadami systemu pomocy psychologicznej w Państwowej Straży Pożarnej zapoznało się 69,1\% ankietowanych.
\end{abstract}

Wnioski. Konieczne jest podniesienie świadomości strażaków w zakresie istotności pomocy psychologicznej w kwestii radzenia sobie ze stresem towarzyszącym pracy.

Słowa kluczowe: stres, strażak, służby ratunkowe

\section{Summary}

Introduction. The aim of the study was to identify sources of occupational stress as seen by fire-fighters, analyse the ways of dealing with it, as well as consider types of the declared health symptoms which occur due to occupational stress.

Material and methods. The surveyed group consisted of 110 firefighters from the Combat Division of the Municipal Command of the State Fire Service in Biała Podlaska. The study was conducted at the turn of 2014/2015, using the diagnostic survey method and the author's own questionnaire survey.

Results. $22 \%$ of the surveyed firefighters declare that they do not feel stressed during their occupational activities. The biggest source of stress for the respondents was the responsibility for the lives of rescued people $(38 \%)$ and the pressure of time in the decision-making process $(25 \%)$. The declared health symptoms of stress included: accelerated breath and heart rate, increased blood pressure (25.5\%), irritability (22.6\%), fatigue (22.6\%). $18.2 \%$ of the respondents sought help from a psychologist and $69.1 \%$ were familiar with the principles of the psychological help system in the State Fire Service.

Conclusions. It is necessary to raise fire-fighters' awareness in terms of the relevance of psychological support in coping with occupational stress.

Keywords: stress, firefighters, emergency services

\section{Wstęp}

Czynniki środowiskowe, określane jako stresory, naruszają równowagę organizmu człowieka aktywując mechanizmy reagowania fizjologicznego i psychologicznego oraz wpływając na stan zdrowia jed- nostki (Grygorczuk 2008). Stresu związanego z pracą zawodową doświadcza niemal co czwarty pracownik i w związku z tym jest on jednym z głównych problemów w zakresie zdrowia publicznego (Łodzińska 2010). Nadmierny stres zawodowy związany z przeżywaniem sytuacji stresowych w miejscu pracy może

Adres korespondencyjny: Małgorzata Tokarska-Rodak, Państwowa Szkoła Wyższa im. Papieża Jana Pawła II w Białej Podlaskiej, Wydział Nauk o Zdrowiu i Nauk Społecznych, Katedra Zdrowia, Zakład Zdrowia Publicznego, ul. Sidorska 95/97, 21-500 Biała Podlaska, e-mail: rodak.malgorzata@gmail.com, tel.: 83 344 99 00. Copyright by: Państwowa Szkoła Wyższa im. Papieża Jana Pawła II w Białej Podlaskiej, Piotr Paweł Oskwarek, Małgorzata Tokarska-Rodak

Czasopismo Open Access, wszystkie artykuły udostępniane są na mocy licencji Creative Commons Uznanie autorstwa-użycie niekomercyjne-na tych samych warunkach 4.0 Międzynarodowe (CC BY-NC-SA 4.0, http://creativecommons.org/licenses/by-nc-sa/4.0/). 
prowadzić do zaburzeń w różnych sferach funkcjonowania człowieka i wpływać w szerokim zakresie na stan jego zdrowia. Należy brać pod uwagę fakt, że percepcja różnorodnych bodźców stresowych odbywa się w sposób subiektywny, a podejmowane przez człowieka w tych warunkach czynności mają na celu minimalizację jego skutków (Stępka, Basińska 2014, Grygorczuk 2008). Według Grygorczuk (Grygorczuk 2008) o efektywności radzenia sobie w sytuacji stresowej decyduje zgodność zachowania z indywidualnym stylem radzenia sobie, niż dostosowanie zachowania do rodzaju sytuacji.

Funkcjonariusze Państwowej Straży Pożarnej (PSP) ze względu na specyfikę pracy i duże obciążenie stresem, częściej niż osoby wykonujące inne zawody, narażeni są na ryzyko wystąpienia znacznych uszczerbków na zdrowiu (Pawlak i in. 2016). Według Karty Charakterystyki Zagrożeń Zawodowych opublikowanej przez Centralny Instytut Ochrony Pracy-Państwowy Instytut Badawczy strażak, to osoba wykonująca czynności ratowniczo-gaśnicze podczas różnego rodzaju zdarzeń (pożarów, katastrof drogowych, katastrof naturalnych) w celu ratowania życia, zabezpieczenia obiektów i minimalizacji szkód materialnych. Strażacy pracują w szkodliwych i gwałtownie zmieniających się warunkach środowiska pracy. Narażeni są na różnorodne czynniki ryzyka w tym zawalające się konstrukcje, czynniki fizyczne (hałas, wysokie i niskie temperatury podczas prowadzenia akcji gaśniczych), czynniki chemiczne i pyły, czynniki biologiczne, czynniki ergonomiczne oraz psychospołeczne i związane z organizacją pracy. Funkcjonariusze straży pożarnej wykonują czynności związane $\mathrm{z}$ dużym wysiłkiem fizycznym przy znacznym obciążeniu odzieżą ochronną, narażeni są na urazy związane $\mathrm{z}$ wypadkami komunikacyjnymi, katastrofami przemysłowymi i powodziami (www.ciop.pl). Ponadto praca strażaków wymaga umiejętności pracy w zespole, współdziałania, umiejętności podporządkowania się rozkazom wydawanym przez przełożonych, charakteryzuje się wysokim poziomem stresu zawodowego i wymaga dużej odporności psychofizycznej. Zdarzenia, w których niezbędne jest udzielenie pierwszej pomocy ofiarom wypadku, przeprowadzenie ewakuacji, zapobieżenie panice, wymagają opanowania, podzielności uwagi, a także umiejętności szybkiego reagowania w sytuacjach kryzysowych. Stres w pracy strażaka nie wiąże się tylko $\mathrm{z}$ udziałem w akcjach ratowniczych (Hetherington 2004, Czarnecka, Dobrodziej 1998, Weiman, Przybylski 2013, Ogińska-Bulik, Kaflik-Pieróg 2009). Strażacy funkcjonują w stanie stałego napięcia nerwowego, w ciągłym oczekiwaniu na alarm i w gotowości do podjęcia działań ratowniczych (Weiman, Przybylski 2013).

W marcu 2009 roku Komendant Główny Państwowej Straży Pożarnej (PSP) wydał decyzję „w sprawie powołania zespołu roboczego do opracowania założeń do organizacji systemu pomocy psychologicznej w krajowym systemie ratowniczo-gaśniczym" (Decyzja Nr 10 Komendanta Głównego Państwowej Straży Pożarnej 2009), co ostatecznie skutkowało przyjęciem „Zasad organizacji i funkcjonowania systemu pomocy psychologicznej w Państwowej Straży Pożarnej". Dokument ten zawiera w swojej treści, zadania dla psychologów w PSP oraz procesy wdrażania Systemu Pomocy Psychologicznej (SPP) (Komenda Główna Państwowej Straży Pożarnej 2016). Celem głównym organizacji takiego systemu jest utrzymanie wysokiej kondycji psychofizycznej strażaków oraz profilaktyka zdrowia psychicznego. Działania podejmowane przez psychologów w PSP sa skierowane na to, by strażak ponosił mniejsze koszty osobiste związane z wykonywana praca (Pluczyńska 2011).

Celem pracy było określenie źródeł stresu zawodowego w opinii strażaków, analiza sposobów radzenia sobie z nim oraz analiza rodzaju deklarowanych symptomów zdrowotnych występujących w związku ze stresem zawodowym.

\section{Materiał i metody}

W badaniach zastosowano metodę sondażu diagnostycznego, w której posłużono się autorskim kwestionariuszem ankiety. Kwestionariusz obejmował 6 pytań metryczkowych i 17 pytań dotyczących: stażu pracy w zawodzie strażaka, zajmowanego stanowiska służbowego oraz subiektywnej oceny w zakresie źródeł stresu odczuwanego w pracy zawodowej, sytuacji stresowych podczas akcji ratowniczych, odczuwanych zdrowotnych symptomów stresu i sposobów jego eliminacji.

Badania ankietowe przeprowadzono wśród 110 strażaków (mężczyzn) Podziału Bojowego Komendy Miejskiej Państwowej Straży Pożarnej w Białej Podlaskiej. Badania przeprowadzono na przełomie roku $2014 / 2015$. Osoby w wieku od 20 do 30 lat stanowiły $25,5 \%$ ogółu badanych, w wieku od 31 do 40 lat - 42,7\%, w wieku od 41 do 50 lat - 30\%, zaś strażacy w wieku powyżej 50 lat - 1,8\%.

Uzyskane wyniki poddano analizie statystycznej. Istotność różnic dla zmiennych o charakterze nominalnym określano testem chi kwadrat. Korelacje pomiędzy zmiennymi porządkowymi sprawdzono za pomoca współczynnika korelacji rang Spearmana. W analizach statystycznych przyjęto poziom istotności $p<0,05$. Analiz dokonywano za pomocą programu SPSS 17.0.0.

\section{Wyniki}

W tabeli 1 przedstawiono zakres odpowiedzi udzielonych przez respondentów na pytania dotyczące miejsca zamieszkania, wykształcenia, stanu cywilnego, liczby dzieci w rodzinie, sytuacji materialnej, stażu pracy w zawodzie strażaka oraz zajmowanego stanowiska służbowego. 
Tabela 1. Charakterystyka badanych osób z punktu widzenia zmiennych podmiotowych i środowiskowych

\begin{tabular}{|c|c|c|}
\hline \multicolumn{2}{|c|}{ Rodzaj cechy socjodemograficznej } & \multirow{2}{*}{$\begin{array}{c}\begin{array}{c}\% \\
\mathbf{N}=110\end{array} \\
60,9\end{array}$} \\
\hline Miejsce & Wieś & \\
\hline zamieszkania & Miasto & 39,1 \\
\hline \multirow{4}{*}{ Wykształcenie } & Wyższe & 32,7 \\
\hline & Średnie & 63,6 \\
\hline & Zawodowe & 2,7 \\
\hline & Podstawowe & 0,9 \\
\hline \multirow{4}{*}{ Stan cywilny } & W związku małżeńskim & 71,8 \\
\hline & W związku nieformalnym & 5,5 \\
\hline & W separacji & 3,6 \\
\hline & Kawaler & 19,1 \\
\hline \multirow{5}{*}{$\begin{array}{l}\text { Liczba dzieci } \\
\text { w rodzinie }\end{array}$} & 1 dziecko & 18,2 \\
\hline & 2 dzieci & 40,9 \\
\hline & 3 dzieci & 9,1 \\
\hline & Więcej niż 3 dzieci & 5,5 \\
\hline & Brak dzieci & 26,4 \\
\hline \multirow{3}{*}{$\begin{array}{c}\text { Sytuacja } \\
\text { materialna }\end{array}$} & Bardzo dobra & 9,1 \\
\hline & Dobra & 80,0 \\
\hline & Zła & 10,9 \\
\hline \multirow{5}{*}{$\begin{array}{c}\text { Staż pracy } \\
\text { w zawodzie }\end{array}$} & $<1$ rok & 1,8 \\
\hline & 1-5 lat & 15,5 \\
\hline & 6-10 lat & 39,1 \\
\hline & 11-15 lat & 17,3 \\
\hline & $>15$ lat & 26,4 \\
\hline \multirow{2}{*}{$\begin{array}{l}\text { Zajmowane } \\
\text { stanowiska } \\
\text { służbowe }\end{array}$} & Dowódca & 35,2 \\
\hline & Inne & 64,8 \\
\hline
\end{tabular}

Dwadzieścia dwa procent $(22,0 \%)$ ankietowanych strażaków deklaruje, że nie odczuwa stresu podczas wykonywania czynności związanych z wykonywanym zawodem. Sytuacje stresowe raz lub dwa razy w miesiącu odczuwało 40,4\% ankietowanych, trzy do czterech razy w miesiącu 13,8\% respondentów. Częściej (od 5 do 7 razy w miesiącu) sytuacje stresowe w trakcie służby odczuło $10,1 \%$ strażaków, zaś 13,8\% ankietowanych strażaków każdorazowo $\mathrm{w}$ trakcie służby odczuwało stres. Nie stwierdzono by odczuwany stres w pracy, był związany z wiekiem ( $p=0,358)$, wykształceniem $(p=0,432)$, stanem cywilnym ankietowanych $(\mathrm{p}=0,557)$, sytuacją materialną $(p=0,211)$, liczbą posiadanych dzieci $(p=0,887)$, stażem zawodowym $(\mathrm{p}=0,452)$ oraz $\mathrm{z}$ zajmowanym przez respondentów stanowiskiem $(\mathrm{p}=0,269)$.

Największym deklarowanym źródłem stresu dla ankietowanych strażaków były: odpowiedzialność za życie osób ratowanych (38\%), presja czasu w podejmowaniu decyzji (25\%), oczekiwanie na alarm $(18,5 \%)$, zagrożenie dla własnego zdrowia $(14,8 \%)$, dojazd na miejsce zdarzenia $(14,8 \%)$ i traumatyczne przeżycia po akcji $(13,9 \%)$. Rzadko źródłem stresu była zmienność warunków środowiska pracy $(7,4 \%)$ i system pracy zmianowej $(4,6 \%)$. Na inne przyczyny stresu niż wymienione w ankiecie wskazało 13,9\% ankietowanych strażaków.

Zdaniem 25,5\% respondentów istnieje możliwość wyeliminowania stresu podczas pracy w straży pożarnej, 65,5\% strażaków było przeciwnego zdania, a 9,1\% osób nie potrafiło w tej kwestii zająć stanowiska.

Najczęściej odczuwane zdrowotne symptomy stresu deklarowane przez ankietowanych strażaków to: przyspieszony oddech, tętno, podwyższone ciśnienie $(25,5 \%)$, rozdrażnienie $(22,6 \%)$, zmęczenie $(22,6 \%)$. Nieco rzadziej deklarowano bóle brzucha $(18,9 \%)$, bezsenność $(17,9 \%)$, zdenerwowanie $(15,1 \%)$, pocenie się $(14,2 \%)$, problemy z koncentracją $(10,4 \%)$, drżenia rąk $(8,5 \%)$, bóle głowy $(7,5 \%)$, strach $(7,5 \%)$, osłabienie $(4,7 \%)$. Na inne dolegliwości wskazało 3,8\% respondentów.

Niemal wszyscy ankietowani strażacy brali udział w akcji, w której były ofiary śmiertelne $(96,4 \%)$. Tylko niecałe 3,6\% ankietowanych nie miało kontaktu $\mathrm{z}$ tego typu sytuacjami. Większość respondentów po trudnej akcji ratowniczej analizowało $\mathrm{z}$ załoga jej przebieg $(82,7 \%)$. Istotnie częściej $(p<0,005)$ takiej analizy dokonywały osoby będące $\mathrm{w}$ związku $(88,2 \%)$ niż osoby samotne (64\%). Niepokojące sny $\mathrm{z}$ przebiegu akcji ratowniczych występowały u 29,1\% respondentów zaś $75,5 \%$ ankietowanych wracało myślami do trudnych akcji ratowniczych, które zdarzały się w przeszłości.

Istotny okazał się wpływ charakteru pracy na jakość życia strażaków w odniesieniu do percepcji odczuwanego stresu $(\mathrm{p}<0,05)$. Osoby uważające, że wykonywana praca ma wpływ na jakość ich życia (76,4\%), odczuwały stres przynajmniej raz w miesiącu. Z grupy osób twierdzacych, że praca nie wpływa na ich jakość życia $(23,6 \%)$ nigdy nie odczuwało stresu $45,8 \%$. W opinii badanych istotny jest wpływ zajmowanego stanowiska służbowego na jakość życia rodzinnego $(p<0,02)$. Z grupy dowódców $90,6 \%$ zadeklarowało, że praca wpływa na ich jakość życia rodzinnego. W grupie pozostałych strażaków odsetek osób twierdzących, że praca ma wpływ na jakość życia wynosił 67,8\%. Odpowiedzi udzielane przez respondentów na pytanie „w jaki sposób praca wpływa na jakość życia rodzinnego" zamieszczono na rycinie 1 . 


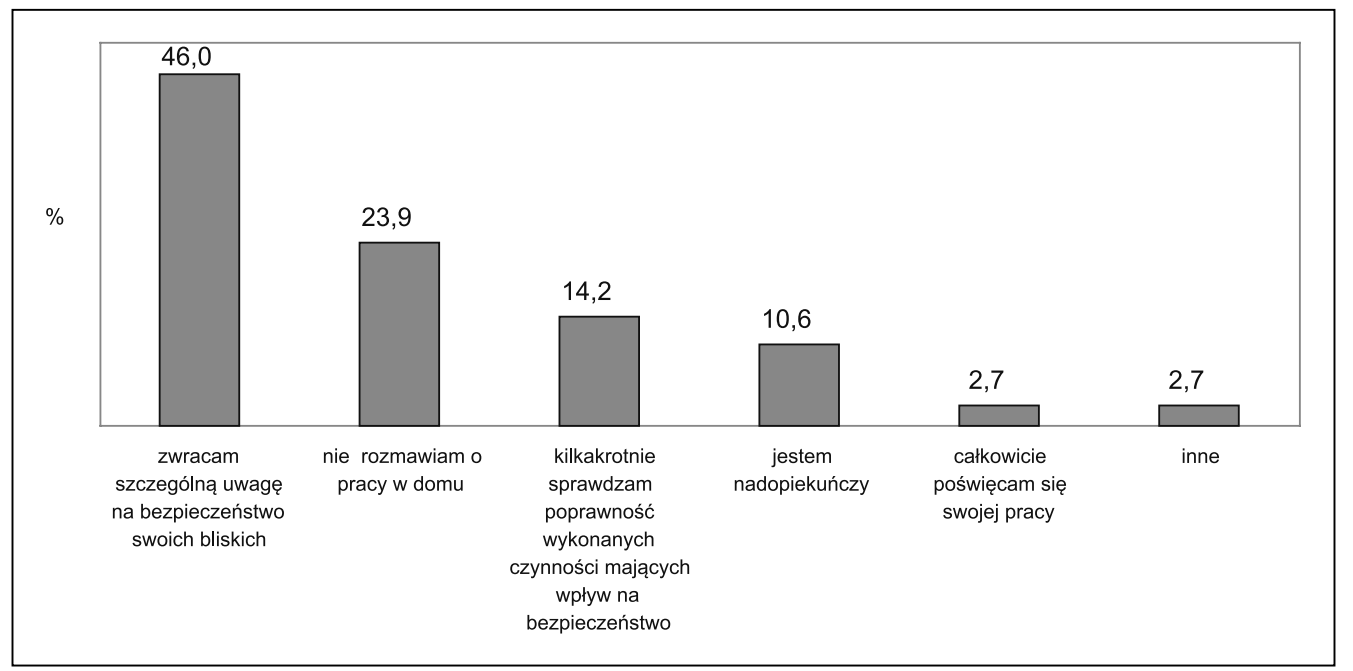

Rycina 1. Wpływ pracy w straży pożarnej na jakość życia rodzinnego w ocenie badanych

W celu zminimalizowania stresu ankietowani strażacy informowali o koncentrowaniu się na problemie i poszukiwaniu sposobu jego rozwiązania (30,3\%), stosowali ćwiczenia fizyczne $(25,7 \%)$, koncentrowali się na pracach domowych lub na pracach na działce $(22,9 \%)$, starali się nie myśleć o zaistniałej sytuacji $(22,9 \%)$, poddawali się relaksacji $(21,1 \%)$. Rzadziej ankietowani deklarowali spotkania ze znajomymi z pracy $(14,7 \%)$, palenie tytoniu $(13,8 \%)$, spożywanie alkoholu $(12,8 \%)$ i medytacje $(9,2 \%)$ zaś 4,6\% respondentów wskazała na inne formy minimalizowania stresu. Zaledwie 18,2\% ankietowanych korzystało z pomocy psychologa, a pozostali respondenci $(81,8 \%)$ nigdy tego nie czynili. Istotną przyczyną $(p<0,02)$, która niewątpliwie wpływa na częstość sięgania po pomoc psychologiczną jest sytuacja materialna ankietowanych. Respondenci deklarujący bardzo dobrą sytuację materialną częściej $(50 \%)$ korzystali z takiej pomocy niż osoby z dobrą $(15,9 \%)$ i złą $(8,3 \%)$ sytuacją materialną. Z zasadami organizacji systemu pomocy psychologicznej w Państwowej Straży Pożarnej zapoznało się 69,1\% ankietowanych zaś pozostali respondenci $(30,9 \%)$ twierdzili, że tych zasad nie znają.

\section{Dyskusja}

Reakcja organizmu na negatywne, długotrwałe i silne działanie czynników stresowych, które pojawiają się zbyt często może przyjąć formę klinicznych manifestacji jak: zespoły bólowe mięśni, choroby wrzodowe układu pokarmowego, bolesne kurcze jelit, obniżenie odporności organizmu i podatność na różnego rodzaju infekcje, choroby układu krążenia, nadciśnienie tętnicze, udary mózgu, zawał mięśnia sercowego, nerwice, lęki, psychozy, depresja i choroby nowotworowe (Boenisch, Haney 2002, Wrześniewski 2000). Wyniki badań przeprowadzonych wśród strażaków Podziału Bojowego Komendy Miejskiej Państwowej Straży Pożarnej w Białej Podlaskiej potwierdzają ogólnie panujące przekonanie, iż zawód strażaka cechuje się wysokim ryzykiem wystąpienia reakcji stresowych. Niewielu strażaków twierdziło, że nigdy nie odczuwało stresu w pracy $(22,0 \%)$. Odpowiedzialność za życie ratowanych ludzi i ich mienie, a także odpowiedzialność za kolegów biorących udział w akcjach ratowniczo-gaśniczych, widok osób ocalonych i rannych mogą powodować u strażaków zaburzenia natury emocjonalnej i funkcjonalnej. $W$ badaniach przeprowadzonych wśród łódzkich strażaków potwierdzono powyższe zaburzenia u niemal $8,4 \%$ badanych (Dudek, Koniarek 2000). W badanej grupie strażaków najczęściej deklarowane zdrowotne symptomy stresu to: przyspieszony oddech, tętno, podwyższone ciśnienie $(25,5 \%)$, rozdrażnienie $(22,6 \%)$, zmęczenie $(22,6 \%)$. Niepokojące sny z przebiegu akcji ratowniczych występowały u 29,1\% strażaków, a aż 75,5\% z nich wracało myślami do trudnych akcji ratowniczych, które zdarzały się w przeszłości.

Stępka i Basińska (Stępka, Basińska 2014) podają, iż funkcjonariusze policji pracujący $\mathrm{w}$ warunkach sprzyjających generowaniu sytuacji stresowych związanych z wykonywanym zawodem najczęściej uskarżali się na pogorszenie koncentracji uwagi i zmniejszenie aktywności, a nieco rzadziej na obniżenie motywacji i subiektywne odczucie zmęczenia.

Jak podkreślono w Międzynarodowej Karcie Charakterystyki Zagrożeń Zawodowych strażacy pracują pod ciągłą groźbą niebezpieczeństwa, a przeżycia związane z przeprowadzonymi akcjami ratowniczymi mogą wywoływać u nich stres pourazowy jak również problemy natury osobistej i rodzinnej (www.ciop.pl). W przeprowadzonych badaniach znaczna większość ankietowanych $(76,4 \%)$ potwierdzała, iż praca w PSP wpływa na jakość ich życia rodzinnego oraz życia pozazawodowego. Ankietowani strażacy stosują zróżnicowane sposoby radzenia sobie z zdrowotnymi symptomami stresu: $82,7 \%$ respondentów analizuje i omawia wspólnie z kolegami z zespołu zaistniałe sytuacje po zakończonej akcji, 30,3\% respondentów pomaga skupienie się na zaistniałym problemie i znalezienie sposobu jego rozwiązania. Ankietowani często skłaniali się ku aktywności fizycznej $(25,7 \%)$ i różnych prac hobbystycznych, rzadziej natomiast sięgali po używki (palenie tytoniu $13,8 \%$, spożywanie alkoholu 12,8\%). Zaledwie $18,2 \%$ ankietowanych korzystało z pomocy psychologa. W analizowanej grupie strażaków nie wszyscy znali 
zasady organizacji systemu pomocy psychologicznej w Państwowej Straży Pożarnej - 30,9\% respondentów nie wiedziało o istnieniu tego typu pomocy.

Według Evans (Evans i in. 2013) powodem nie podejmowania aktywnego szukania pomocy, w tym pomocy psychologicznej, w obliczu sytuacji stresowych może być obawa przed postrzeganiem przez innych jako osoby słabej. Stępka i Basińska podają, że najczęściej stosowaną strategią radzenia sobie ze stresem wśród funkcjonariuszy policji było myślenie pozytywne i bezpośrednie działanie, rzadziej szukanie pomocy i używanie substancji pobudzających, w tym alkoholu (Stępka, Basińska 2014). Badania przeprowadzone przez Stańczak (Stańczak i in. 2014) wśród pracowników sektora bankowego wykazały, że zarówno samo występowanie, jak i subiektywnie odczuwana stresogenność analizowanych psychospołecznych zagrożeń $\mathrm{w}$ tej grupie osób wiąże się $\mathrm{z}$ gorszą oceną zdrowia fizycznego, obniżeniem zdolności do pracy i mniejszym zadowoleniem z pracy oraz silniejszą motywacją do jej zmiany.

Stres dotykając człowieka jako jednostkę społeczną, dotyka jednocześnie jego rodziny, przyjaciół oraz współpracowników (Łodzińska 2010). W zawodzie strażaka problem ten związany jest $\mathrm{z}$ wykonywaniem czynności potencjalnie niebezpiecznych i nie jest możliwe jego wyeliminowanie, a jedynie ograniczenie jego skutków. Duże obciążenie psychofizyczne i nie podjęte w porę kroki zaradcze mogą doprowadzić do wypalenia zawodowego, wpłynąc destrukcyjnie na życie zawodowe i osobiste strażaków (Ogińska-Bulik, Kaflik-Pieróg 2009, Sęk 2000). W zawodzie strażaka, tak jak w innych zawodach o wysokim obciążeniu emocjonalnym, na pewne doznania stresowe można się przygotować korzystając z wsparcia psychologicznego tak, by był on jak najmniejszym obciążeniem. (Łodzińska 2010).

\section{Wnioski}

Konieczne jest podniesienie świadomości strażaków w zakresie istotności pomocy psychologicznej w kwestii radzenia sobie ze stresem towarzyszącym pracy.

\section{Podziękowania}

Panu Komendantowi Miejskiemu Państwowej Straży Pożarnej w Białej Podlaskiej za umożliwienie przeprowadzenia badań ankietowych wśród strażaków Podziału Bojowego.

Panu prof. nadzw. dr hab. n. med. Krzysztofowi Jeziorskiemu za udzieloną pomoc podczas tworzenia treści merytorycznych.

\section{Literatura:}

1. Boenisch E., Haney H.C. (2002), Twój stres. GWP, Gdańsk.

2. Centralny Instytut Ochrony Pracy-Państwowy Instytut Badawczy, Karta Charakterystyki Zagrożeń Zawodowych, www.ciop.pl. (data dostępu: 28.09.2016).

3. Czarnecka A., Dobrodziej C. (1998), Zespół zaburzeń po stresie urazowym w służbach ratowniczych. Przegląd Pożarniczy, 6, s. 20-21.

4. Decyzja Nr 10 Komendanta Głównego Państwowej Straży Pożarnej. W sprawie powołania zespołu roboczego do opracowania założeń do organizacji systemu pomocy psychologicznej w krajowym systemie ratowniczo-gaśniczym. 2009. http://www.zzsflorian.kwpsp.wroc.pl/version_older/i/decyzja_nr_10_o_powolaniu_zepolu.pdf (data dostępu: 29.09.2016).

5. Dudek B., Koniarek J. (2000), Zespół zaburzeń po stresie urazowym (PTSD) wśród funkcjonariuszy PSP - uwarunkowania i skutki. Opracowanie systemu zapobiegania i ograniczania negatywnych konsekwencji tego zespołu. IMP, Łódź.

6. Evans R., Pistrang N., Billings J. (2013), Police officers' experiences of supportive and unsupportive social interactions following traumatic incidents. Eur. J. Psychotraumatol, 4, doi: 10.3402/ejpt.v4i0.19696. https://www.ncbi.nlm.nih.gov/pmc/articles/PMC3600426/ (data dostępu: 30.01.2017).

7. Grygorczuk A. (2008), Pojęcie stresu w medycynie i psychologii. Psychiatria, 5, s. 111-115.

8. Hetherington A. (2004), Wsparcie psychologiczne w służbach ratowniczych. GWP, Gdańsk.

9. Łodzińska J. (2010), Stres zawodowy narastająym zjawiskiem społecznym. SEMINARE 28, s. 125-138

10. Ogińska-Bulik N., Kaflik-Pieróg M. (2009), Stres Zawodowy w służbach ratowniczych. Wydawnictwo Akademii Humanistyczno-Ekonomicznej w Łodzi. Łódź.

11. Pawlak A., Gotlib J., Gałązkowski R. (2016), Analiza występowania i skutków wypadków w środowisku pracy strażaków Państwowej Straży Pożarnej w Polsce w latach 2008-2013. Medycyna Pracy, 67(1), s.1-9.

12. Pluczyńska J. (2011), Poznaj swojego psychologa. Przegląd Pożarniczy Miesięcznik Państwowej Straży Pożarnej 1, 44. https://issuu.com/ppoz.pl/docs/pp111 (data dostępu: 29.09.2016).

13. Sęk H. (2000), Wypalenie zawodowe. Przyczyny. Mechanizmy. Zapobieganie. PWN, Warszawa, s. 149-167.

14. Stępka E., Basińska M.A. (2014), Zmęczenie przewlekłe a strategie radzenia sobie ze stresem w pracy u funkcjonariuszy policji. Medycyna Pracy, 65(2), s. 229-238.

15. Stańczak A., Mościcka-Teske A., Merecz-Kot D.(2014) Zagrożenia psychospołeczne a funkcjonowanie zawodowe pracowników sektora bankowego. Medycyna Pracy, 65(4), s. 507-519.

16. Weiman M., Przybylski K. (2013), Identyfikacja zagrożeń na stanowiskach pracy strażaków zawodowych. Zeszyty Naukowe Politechniki Poznańskiej, Organizacja i Zarządzanie, 59, s. 69-84. http://www.zeszyty. fem.put.poznan.pl/numery/ZN_OiZ_PP_59_06.pdf (data dostępu: 28.09.2016).

17. Wrześniewski K. (2000), Style rädzenia sobie ze stresem. Wydawnictwo Uniwersytetu Śląskiego, Katowice.

18. Zasady organizacji i funkcjonowania systemu pomocy psychologicznej w Państwowej Straży Pożarnej. Komenda Główna Państwowej Straży Pożarnej, 2016 http://www.straz.gorzow.pl/wp-content/ uploads/2016/08/Zasady-organizacji-i-funkcjonowanie-Systemu-Pomocy-Psychologicznej-w-PSP.pdf (data dostępu: 29.09.2016). 